\title{
Is EMI Enough? Perceptions from University Professors and Students
}

\author{
Kathleen Anne CORRALES* \\ Lourdes A. PABA REY** \\ Nazira SANTIAGO ESCAMILLA***
}

\begin{abstract}
Internationalization of higher education aims to develop foreign language and intercultural and international competences (IIC). To achieve this, universities worldwide have implemented strategies such as teaching content subjects in English, also known as English mediated instruction (EMI). However, there is scant research on the positive and negative aspects related to EMI implementation in Latin America. For this reason, this case study explores the perceptions of a group of computer science professors, students, and the program administrator in a Colombian university about the use of this approach in learning content and language and the development of IICs. Results revealed that implementing this initiative has benefits but also poses some challenges. Therefore, we offer recommendations related to the institution as a whole, the professors, and the students and suggest including some elements of the CLIL approach to support learning. It is hoped that these findings will contribute to the worldwide EMI/CLIL discussion, especially in Latin American where this practice is relatively new.
\end{abstract}

Keywords: English medium instruction; intercultural education; international education; higher education.

* orcid.org/oooo-0oo1-6778-3925. Universidad del Norte, Colombia. kwade@uninorte.edu.co

** Universidad del Norte, Colombia. arey@uninorte.edu.co

*** Universidad del Norte, Colombia. santiagon@uninorte.edu.co

Received: 2016-10-07 / Sent for peer review: 2016-10-10 / Accepted by peers: 2016-11-08 / Approved: 2016-11-11 To reference this article in APA style / Para citar este artículo en APA / Para citar este artigo professors and students. Latin American Journal of Content and Language Integrated Learning, 9(2), 318-344. doi:10.5294/laclil.2016.9.2.4 


\title{
¿Es suficiente el uso del inglés como medio de instrucción? Percepciones de estudiantes y profesores universitarios
}

\begin{abstract}
Resumen
La internacionalización de la educación superior tiene como objetivo el desarrollo de competencias interculturales e internacionales (CII) y el desarrollo de la lengua extranjera. Para lograr esto, las universidades en todo el mundo han implementado estrategias como la enseñanza de materias y contenidos en inglés, también conocida como el uso del inglés como medio de instrucción (en inglés: EMI). Sin embargo, hay aún escasa investigación sobre los aspectos positivos y negativos relacionados con la implementación de este enfoque en América Latina. Por esta razón, este estudio de caso explora las percepciones de un grupo de profesores de ciencias de la computación, de estudiantes y del administrador del programa en una universidad colombiana, en relación con el uso de este enfoque en el aprendizaje de contenidos y lengua y el desarrollo de las competencias interculturales e internacionales. Los resultados del estudio indican que la implementación de esta iniciativa ofrece beneficios, pero también plantea algunos retos. Por lo tanto, se generan algunas recomendaciones que conciernen a la institución como tal, a los profesores y los estudiante y se plantean algunos elementos del enfoque AICLE para apoyar el aprendizaje. Se espera que estos resultados contribuyan al análisis de la discusión del enfoque AICLE y EMI, especialmente en América Latina, en donde esta práctica es relativamente nueva.
\end{abstract}

Palabras clave: inglés-medio de instrucción; educación intercultural; educación internacional; educación superior. 


\section{O uso do inglês como meio de instrução é suficiente? Percepções de estudantes e professores universitários}

\section{Resumo}

A internacionalização do ensino superior tem como objetivo o desenvolvimento de competências interculturais e internacionais (CII) e o desenvolvimento da língua estrangeira. Para atingir isso, as universidades em todo o mundo têm implantado estratégias como o ensino de matérias e conteúdos em inglês, também conhecida como o uso do inglês como meio de instrução (em inglês, EMI). Contudo, há uma escassa pesquisa sobre os aspectos positivos e negativos relacionados com a implantação dessa abordagem na América Latina. Por essa razão, este estudo de caso explora as percepções de um grupo de professores de ciências da computação, de estudantes e do administrador do programa numa universidade colombiana, com relação ao uso dessa abordagem na aprendizagem de conteúdos e língua e no desenvolvimento das CII. Os resultados do estudo indicam que a implantação dessa iniciativa oferece benefícios, mas também apresenta alguns desafios. Portanto, geram-se algumas recomendaç̧ões que concernem à instituição, aos professores e aos estudantes, e propõem-se alguns elementos da abordagem AICLE/CLIL para apoiar a aprendizagem. Espera-se que esses resultados contribuam para a análise da discussão da abordagem AICLE/CLIL e EMI, especialmente na América Latina, onde essa prática é relativamente nova.

Palavras-chave: educação intercultural; educação internacional; ensino superior; inglês como meio de instrução. 


\section{INTRODUCTION}

Globalization has been the catalyst for the spread of internationalization processes at higher education institutions (HEIs) around the world. While the concept has been defined in many ways, one of the most accepted definitions was proposed by Knight (2003), and augmented by de Wit (2016) as "the process of integrating an international, intercultural, or global dimension into the purpose, functions or delivery of post-secondary education" (Knight, 2003, p. 2) "in order to enhance the quality of education and research for all students and staff and to make a meaningful contribution to society" (de Wit, 2016). Thus, while the internationalization process has been implemented using various models, depending on the context of the HEIs, there is a close bond between internationalization and culture (Montgomery, 2008) and language development (Kubota, 2009) as seen in the definition by Yang (2002) that focuses on the role of higher education institutions in the development of intercultural and international competences:

For a university, internationalisation means the awareness and operation of interactions within and between cultures through its teaching, research, and service functions, with the ultimate aim of achieving mutual understanding across cultural borders. For a national higher education system, internationalisation refers to dialogue with those in other countries. (p. 83)

More and more, universities are implementing formal and informal learning experiences to expand students' knowledge and skills. These experiences can be field-specific and can also promote the development of particular competences that facilitate effective participation in diverse contexts. Among these competences, Soria and Troisi (2014) have included knowledge and appreciation for cultures, openness to diversity, and the capacity to interact with others comfortably. These skills have been termed as international and intercultural competences (IIC). There is a very interesting body of literature about what IIC are. Several disciplines have enriched this work including perspectives from language learning (Byram, 1997), sociology (Bennet \& Bennet, 2004), and intercultural communication 
(Deardoff, 2006). International and intercultural competences embrace cognitive, affective, and behavioral domains (Deardoff, 2006). In sum, IIC imply a deep comprehension of one's own culture, the capacity of being flexible, the ability to exercise one's profession at international level, and the ability to respond and interact accurately in situations in which different cultures interplay. All these skills are required in XXI century professionals and, in the push for internationalization, modern universities view themselves as responsible for fostering the development of these in their learners, especially since, as Montgomery (2008) argues, "the development of intercultural competence ... should be considered to be an integral aim of internationalization" (p. 17).

Much of the efforts of internationalization of the HEIs have focused on student and faculty mobility; however, in 1999, Nilsson began a new model of internationalization that focuses on giving all students the opportunity to develop IICs without leaving their home institution: Internationalization at Home (IaH). Beelen and Jones (2015) define this initiative as "the purposeful integration of international and intercultural dimensions into the formal and informal curriculum for all students within domestic learning environments" (p. 8). Whereas other internationalization efforts often do not reach the majority of students through activities that are "embedded within the core formal and informal curriculum" in a systematic, planned way, the objective of IaH is that $100 \%$ of students are able to develop themselves to become world citizens with an awareness of cultural similarities and differences and create relationships across borders. IaH is often used in conjunction with other internationalization initiatives, but it is especially useful for those institutions whose student population is unable to study abroad because of financial or personal difficulties. However, implementing internationalization at home effectively has been challenging for many institutions. For this reason, many scholars and academics in the area are calling for faculty education to support the development of programs, courses, and activities to meet this very demanding objective (Beelen \& Jones, 2015).

While IaH does not require that courses be taught in a particular language in order to become internationalized (Beelen \& Jones, 2015), more and more universities have shifted to using a common language (albeit, 
often alongside the official language of the nation). Despite the controversy around the spread of English, sometimes called "Englishization", and its effect on the "ecology of languages" (see, for example, Doiz, Lasagabaster, \& Sierra, 2013; Cots, Lasagabaster, \& Garrett, 2012; Byun et al., 2011), English currently has positioned itself as the lingua franca of academics and research. It is for this reason that English Medium Instruction (EMI), defined simply as "using English for teaching and learning" (Smit \& Dafouz, 2012, p. 2), has become a recent trend at the university level.

In Europe, the Netherlands and Nordic countries were pioneers in using EMI (Doiz, Lasagabaster, \& Sierra, 2011), and its spread has reached even countries that in the past had little English as a foreign language learning tradition, such as Italy, Greece, and Spain (Doiz, Lasagabaster, \& Sierra, 2013). This explosion was documented by Wächter and Maiworm (2008) who reported in 2007 that 700 bachelor courses and master's programs were being offered entirely in English in HEIs in Europe, up 340\% from what was offered in 2002. In 2014, this number was much greater; Wächter and Maiworm (2014) found 8,000 bachelor courses and master's programs were being offered in English in Europe. It is likely that this number has continued its exponential growth. Currently, EMI has extended globally to Asia, Africa, the Middle East, and Latin America.

The spread of EMI can be tied to various social, political, and historical factors, some of which are directly related to internalization initiatives. In Europe, and partly through the ERASMUS, SOCRATES, and LEONARDO programs, its growth has been fueled by the push to promote a multilingual Europe (Ali, 2013; Aguilar, 2015). Additionally, EMI is seen to support economic objectives related to raising university revenue by drawing both local and international students to the university (Mortensen \& Haberland, 2012). Quality indicators and international rankings are also an important reason for its growth (Gazzola, 2012; Cots, Lasagabaster, \& Garrett, 2012). Furthermore, as Altbach (2004) has pointed out, universities have always been global institutions. Therefore, since they have the responsibility of preparing future professionals to become world citizens who can successfully "compete" in the modern world (Haigh, 2014), EMI has been perceived as a tool to build competence in the "language of knowledge" (Ali, 2013, p. 74). Some authors have suggested that English language 
development seems to be a secondary aim of policy-makers when implementing EMI experiences (Ali, 2013; Smit \& Dafouz, 2012).

While the term EMI is relatively new, the concept of combining language and content is not. Examples of this mixture can be seen in the French immersion programs in Canada in the late 1950s, in content-based instruction (CBI) bilingual education programs, especially in the United States, and in content and language integrated learning (CLIL), found mainly in Europe. However, as Aguilar (2015) mentions, often the terms CLIL and EMI are confused and used indiscriminately. Even though the implementation of CLIL is varied, in order to be labeled as CLIL, the approach must fuse language and content together and contain each explicitly as learning objectives (Coyle, Hood, \& Marsh, 2010). Therefore, as Smit and Dafouz (2012) point out, courses that lack this fusion-as the significant majority of the EMI programs do because of their focus purely on content-would not be labeled as CLIL. However, they also argue that when viewed from a discursive perspective in which meaning is co-constructed through interactions, the integration of content and language occurs in EMI classes, irrespective of the explicit teaching aims (Smit \& Dafouz, 2012). This article uses the term CLIL to describe the type of education where both language and content are objectives of the course and the term EMI to describe "the type of context where content is the priority and where no assessment of students' English competence is made because no language learning outcomes are acknowledged" (Aguilar, 2015, p. 4, based on the distinction of Greere \& Räsänen, 2008).

The interest in EMI can clearly be seen in the plethora of research projects and articles that have been published worldwide within the past decade. Literature includes descriptive studies of the various contexts and forms of EMI implementation globally (see for example Maiworm \& Wächter, 2002; Doiz, Lasagabaster, \& Sierra, 2011; Costa \& Coleman, 2013) and other studies to see the effect of EMI implementation on curriculum, students, and professors.

EMI has been found to be beneficial (Paseka, 2000; Ruiz-Garrido \& Palmer-Silveira, 2008; among others), especially in regions that have a long tradition of English language learning and implementation of EMI. Smith (as cited in Coleman, 2006) argues that the benefits of EMI outweigh the 
drawbacks. However, studies suggest that the use of EMI does not guarantee only positive benefits, at least in certain contexts (Byun et al., 2011). One cause of this could be a gap between institutional policies and practice (Ali, 2013; Hu, Li, \& Lei, 2014). Additionally, when taught by non-native English speaking professors, EMI has been found to increase the workload for those professors (Sercu, 2004), who have to invest more time in preparing for the lessons, and students (Kim as cited in Byun et al., 2011) by causing less classroom interaction (Airey \& Linder, 2006), with the result that professors cover less material or cover it more superficially (Olsten \& Hukin, 1990), which can affect the understanding and learning of content (Sert, 2008; Kırkgöz, 2009). Thus, many studies call for professional development to support effective EMI implementation by professors (Paseka, 2000; Byun et al., 2011; Jensen \& Thøgersen, 2011; Costa \& Coleman, 2013; Aguilar, 2015).

Because EMI courses are taught in countries where English is not often the native language, research has looked at the relationship between EMI and linguistic aspects. Studies demonstrate that most EMI professors believe that their role is to teach content; therefore, they do not correct language errors or teach language aspects (Airey, 2011; Aguilar \& Rodriguez, 2012; Aguilar, 2015). However, partly refuting this, Costa (2012) determined that professors used pre-emptive focus on form in their classes, which means that the meaning of a lexical item is explained or provided, but this may be attributed to the pedagogical aspects related to teaching content and not to an awareness of the language needs of the students. Unterberger's (2012) study also found that course syllabi included functional language learning aims such as giving presentations, developing discussion and negotiation skills, and learning technical vocabulary. Nevertheless, in general, there is a lack of explicit language goals in EMI course descriptions (Costa \& Coleman, 2013). This focus on content is confirmed by the fact that sometimes both students and professors recur to the native language of the context in order to support learning (Ljosland, 2011; Söderlundh, 2013).

As the literature on EMI demonstrates, EMI implementation is becoming more and more extensive worldwide; however, very little attention has been paid to the positive and negative aspects of its implementation 
in Latin America. Additionally, although EMI has been linked to internationalization efforts, little has been said about its role in the development of international and intercultural competences. Dervin and Hahl (2015) in Finland and Spiro (2011) in an online environment studied the development of intercultural competences in EMI teacher education programs; however, there is no mention of the effect of EMI on this development. For this reason, the objective of the study was to view the perceptions of the Department Director, professors, and students of a computer science program in a Colombian university concerning the effects of participating in an EMI course and the influence of the course on their development of IIC.

\section{METHOD}

\section{Context}

Internationalization processes have become strategic for HEIs worldwide. Colombian universities view this current trend as twofold: educating successful professionals to be able to work in the globalized world and, simultaneously, contributing to constructing worldwide scientific knowledge. One way that Colombian HEIs have met this challenge is by promoting inbound and outbound mobility, conducting joint research, offering dual-degree programs, and building students' IICs. English is important to all of these processes.

During the last decade, Colombia has focused its efforts on competing in international markets, which has led, among various initiatives, to the implementation of a foreign language policy. Although Colombia's official language is Spanish, due to the positioning of English as the language of business and science, policy-makers selected it as the foreign language to be learned in the country (Corrales, Ferrer, \& Rey, 2015). Therefore, the Ministry of Education mandated English as the language to be studied in the public schools of the country and has also established specific language-level goals for English development to be achieved by learners at all levels of the education system. This study focuses, then, on how these two realities are embraced by a Colombian private university: English language learning and internationalization of the university. 
The particular context of the study is a private, non-profit university with a student population of 14,000 students and about 500 full-time faculty. As is the case of many universities around the world, this university has also begun a comprehensive internationalization process. The institutional commitment towards internationalization is evident in its development plan for 2012 to 2017 where this area is an overarching strategic objective. Historically, the university has implemented "internationalization" actions such as annual forums focused on different regions of the world (e.g., European Forum, Asian Forum, Latin American Form, and the United States Forum). Additionally, the university uses a mixture of broad internationalization strategies to foster student and staff mobility, international research projects, dual-degree programs, international internships, among others. However, leaders of the university have realized that the majority of its students are not able to take advantage of these international opportunities, so it has embraced IaH as defined by Beelen and Jones (2015). Among the various formal and informal international activities, the academic divisions implement, it is worth mentioning that foreign language learning has an important position. The university has established a foreign language graduation requirement for all undergraduate students, has implemented parallel-language teaching (e.g., lectures given in the mother tongue and class materials in English), and is offering some English medium instruction courses.

Beginning as a top-down decision, EMI was implemented for several reasons in this context. First, it helps to attract international study-abroad students because it allows them to take courses in English, regardless of their Spanish level. Additionally, it allows local students to "get a taste" of what an outbound mobility experience could be like. The use of English in these classrooms has been viewed by the administration as a way for students to learn and work with the content of their field, thereby preparing them for the workplace without having to leave the country.

As mentioned earlier, there is a lack of studies related to EMI in Latin America, in general, but also specifically regarding the perceptions of the participants in an EMI experience in this region of the world. Therefore, this study aims to contribute to the areas of Internationalization and EMI by answering two research questions. 
- What do professors, students, and the program administrator of a computer science program believe are the advantages and disadvantages of participating in an EMI experience?

- What perceptions do they have in relation to the development of IIC as a result of the EMI experience?

\section{Participants}

The case study described in this article was carried out in two courses of a Computer Science program, Digital Design and Database. These courses are offered during the fifth and six semesters, respectively. During the period the study took place, these were the only two classes in the program that were taught in English. Therefore, the participants were the two professors who taught the aforementioned courses, the Department Director who was the administrator of the program, and the 27 students who were enrolled in the courses.

One of the reasons why these particular courses were taught in English was because of the English level of the professors. Both professors had completed their doctorate degrees in the United States; therefore, they had a competent level of English, particularly in their field of study.

Because the courses were taught in English, we began with a background review of the levels of English that the students had taken before enrolling in the courses under study (see Figure 1). As can be seen, over half of the students had already finished the last or second-to-last level of the university's eight-level English program, while approximately $32 \%$ of the students were taking the level of the English courses that aligned with their semester (levels five or six). According to the language aims of the English program, level five is finishing a B1 and levels six through eight are developing a B2 level of language, according to the Common European Framework of References (CEFR). A small percentage of the students were much below the level that was expected. Finally, and not represented in the figure, one student was taking French as his foreign language requirement. 


\section{Figure 1. Levels of English that students had completed before enrolling in courses}

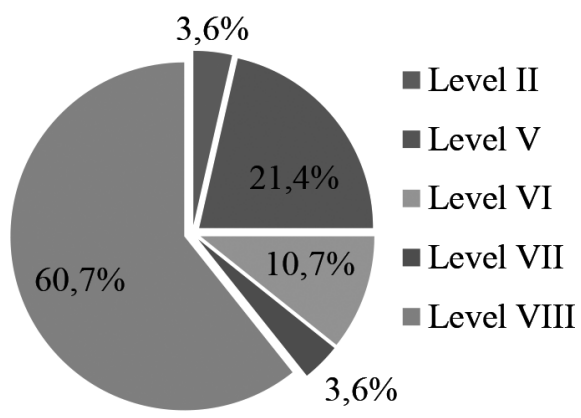

\section{Instruments}

Three main data collection techniques were used to gather information from the participants. These were interviews, a questionnaire, and class observation. The semi-structured interviews were carried out separately with each of the professors and with the program Department Director and contained a series of questions aimed at gaining an understanding of their perceptions of the EMI process. The interviews were transcribed, coded, and analyzed.

An anonymous paper-based questionnaire with six closed statements and three open questions was used to gather data about the EMI experience from the students. The six closed statements related to the EMI experience, and students were asked to rate their level of agreement according to a four-level, Likert-type scale of strongly agree, agree, disagree, or strongly disagree. The open questions asked students to write their answers. The questionnaire was written in Spanish to allow for richer data, but the questions and statements are translated into English for this article. This was piloted on a group of students who participated in an earlier EMI experience in the same university, and a few items were revised based on the piloting process.

It is important to note that while there were 27 students enrolled in the course, only 18 answered the questionnaire. Therefore, the results of the questionnaire are based on these 18 students. Furthermore, not all students answered each of the questions, so there may be discrepancies 
in the total number answered for each part. However, the percentages that are given for the results are based on the number of students that answered each question.

Related to the observation process, the researchers decided to observe the teaching of one topic or unit of each course. The purpose of these observations was to confirm the answers that the students gave on their questionnaires and the information that the professors provided during their interviews; for this reason, the observations were not recorded and transcribed, but an observation format was designed. The timetable for the observations was made in conjunction with the professors of the courses.

\section{Data analysis process}

Both the results from the interviews and the open questions of the surveys were analyzed using qualitative methods. According to Bogdan and Biklen (1992), this type of analysis implies "working with data, organizing it, breaking it into manageable units, synthesizing it, searching for patterns, discovering what is important and what is to be learned, and deciding what you will tell others" (p. 145). Thus, in the research process, data from the interview transcripts, the open questions on the student questionnaires, and the notes on the observation formats were reviewed to find patterns and labeled into categories. Drawing on Martin and Booth's (1997) phenomenographic idea of a "pool of meaning" (p. 133) and Airey's (2001) notions, the data from the instruments were put together to document the perspectives expressed by the participants on their EMI experience. Descriptive statistics was also used to analyze the closed questions of the student questionnaire.

\section{RESULTS}

Initially, we discuss the results focused on answering the first research question, which was related to the advantages and disadvantages of participating in an EMI experience, as perceived by the students, professors, and the program administrator. Then we will turn our attention to the second question, which deals with the development of IICs. 
Analysis of the participants' responses showed that although the focus of these courses was content, as in most EMI experiences, language played an important role in its implementation as the success of the experience depended greatly on students' English level. According to the student survey (see Table 1), the overwhelming majority of students believe that their English level was sufficient to cope with the challenge of learning content through English and that it did not impede their learning of computer science content. As the professors mentioned in the interviews, this could possibly be because the subjects themselves were very technical and hands-on. However, $28 \%$ of the students expressed that they had problems understanding the concepts taught in the class. The professors and Department Director agree that the attainment of the course goals is closely tied to student language level, as has been noted in other studies of EMI internationally (Sert, 2008; Kırkgöz, 2009).

\section{Table 1. Student responses on the closed section of the questionnaire}

\begin{tabular}{|c|c|c|c|c|c|c|c|c|}
\hline & \multicolumn{2}{|c|}{$\begin{array}{c}\text { Strongly } \\
\text { agree }\end{array}$} & \multicolumn{2}{|c|}{ Agree } & \multicolumn{2}{|c|}{ Disagree } & \multicolumn{2}{|c|}{$\begin{array}{l}\text { Strongly } \\
\text { disagree }\end{array}$} \\
\hline & $\mathbf{n}$ & $\%$ & $\mathbf{n}$ & $\%$ & $\mathbf{n}$ & $\%$ & $\mathbf{n}$ & $\%$ \\
\hline $\begin{array}{l}\text { 1. My language is at an appropriate level } \\
\text { to take this class in English. }\end{array}$ & 8 & 44 & 7 & 39 & 1 & 6 & 2 & 11 \\
\hline 2 I understand clearly the concepts taught. & 9 & 50 & 4 & 22 & 3 & 17 & 2 & 11 \\
\hline $\begin{array}{l}\text { 3. My English level has been an impedi- } \\
\text { ment to learn the content of the course. }\end{array}$ & 2 & 11 & 3 & 17 & 1 & 6 & 12 & 66 \\
\hline $\begin{array}{l}\text { 4. My English has improved by being in } \\
\text { this class. }\end{array}$ & 3 & 21 & 6 & 43 & 4 & 29 & 1 & 7 \\
\hline $\begin{array}{l}\text { 5. Taking academic classes in English } \\
\text { should be a part of the education of pro- } \\
\text { fessionals at this university. }\end{array}$ & 10 & 59 & 7 & 41 & & & & \\
\hline $\begin{array}{l}\text { 6. This course contributed to the develop- } \\
\text { ment of my international and intercul- } \\
\text { tural competencies. }\end{array}$ & 10 & 56 & 8 & 44 & & & & \\
\hline
\end{tabular}

As found in other studies on EMI (Airey, 2011; Aguilar \& Rodriguez, 2012; Aguilar, 2015), the professors of these classes do not correct language errors or explicitly take language into account because they "are not language teachers.” Thus, they focus completely on content teaching 
and learning. One professor stated that he "would be worried if students cared about language development" because the course was a computer science class.

This does not mean that the participants did not find value in EMI with regard to language. Some advantages identified by all participants are related to the opportunity to practice English and enhance students technical vocabulary. Table 1 shows that $64 \%$ of the students who completed the questionnaire felt that their English level improved. When asked about the gains of participating in this experience, the majority of the responses related to the development of the technical English of their major and English in general, including listening skills. The professors and Department Director emphasized that students were able to employ English in authentic communicative situations, allowing them to become more confident, strategic, and resourceful when using the language. This was also confirmed in the observations of the courses where students were seen to ask and respond to the professors' questions. While sometimes not in accurate language, students were able to make their utterances comprehensible. However, an aspect that is important to mention is that both Spanish and English were used in the classes. During the sessions, professors used Spanish to give announcements at the beginning and end of the class, but when they lectured on the content material, English was used. When students spoke to the professors during the whole-class lectures, they spoke in English; however, when working in groups, most students spoke in Spanish. When discussing with students in the small groups, professors would respond using the language in which they had been addressed. This recurrence to the native language is in line with results of other EMI studies (Ljosland, 2010; Söderlundh, 2013; Costa, 2012).

Students, professors, and the Department Director concurred that they believe the EMI class prepared students for future jobs where they might need to use English. The Department Director explained that recently local companies have expressed a need for computer science professionals to be fluent in English because often they provide services to companies in the United States.

Furthermore, when looking at the data, it is clear that the students in this particular study found the EMI experience to be positive because 
they stated that they felt students of the university should take courses in English during their university major, as seen in Table 1. The Department Director and one of the professors also concurred with this view.

A disadvantage of the EMI approach is related to the reason for its implementation at this university. Both professors and students have no clear understanding of the purpose of this practice. The student questionnaire showed that they listed a variety of reasons, with the most salient related to an awareness of the importance of English for their profession (i.e., being able to access the technical content of their field in English), compliance with international accreditation requirements, and institutional internationalization goals such as broadening the courses offered to international students or preparing them to study abroad themselves. While stating that they were not quite sure why they taught in English, the professors offered several possibilities: two-way student mobility and preparing students for future jobs.

The professors also explained that they felt that their courses were chosen to be taught in English because of their level in the language and the fact that they had completed their doctoral studies in English-speaking countries. As mentioned above, they felt that the content of the courses they taught could easily be delivered in English. Nevertheless, professors stated that their selection as well as that of the subject was a top-down decision made by the administration of the program where they had no choice as to whether they would participate in the EMI experience. One professor even mentioned that he felt uncomfortable teaching in English and disagreed with the policy of offering EMI classes. This same professor expressed his concern about the percentage of English use in the class, even suggesting that some of the courses offered in English could be characterized as fake EMI because often only 40 percent of the class was taught in English. Thus, as mentioned earlier, changing to the native language is sometimes necessary, depending on the complexity of the topic. In addition, the Department Director pointed out that in the past, professors have switched to teaching in Spanish because of students' resistance to learning field-content in English. In fact, one of the professors reported that he negotiated with the students the language to be used in the class. This 
clearly indicates the lack of clarity on the reasons behind teaching subjects in English.

A further disadvantage raised by the Department Director relates to the fact that the professors who teach in English do not interact with each other. This means that professors are left to their own devices to cope with teaching content in English to non-native English speakers, implying that they are not aware of best practices that other teachers may have successfully implemented.

One of the purposes of offering EMI courses and of the internationalization of higher education process, in general, relates to the development of the IICs. For this reason, the second research question aimed to find out about the perceptions of the participants in relation to the development of IIC as a result of the EMI experience. As is demonstrated in Table 1, all of the students agreed that the EMI experience allowed them to develop these IIC. However, when asked to identify which IICs were developed during the course, many students responded that they did not know. About half of the students cited an aspect related to English skills such as technical vocabulary, fluency in a foreign language, development of professional conversations, and the ability to "generate knowledge without language becoming an impediment [authors' translation]." Only one student listed other types of competences such as leadership, teamwork, and responsibility.

The professors and the Department Director also showed this trend of focusing only on aspects related to language when asked what IICs were developed in the courses. Their responses pertained to developing English, building technical vocabulary, and practicing the language. The Department Director stated outright that with regards to "the topic of culture, the courses do not relate because the topics are technical. So, for example, the idea of internationalization at the cultural level does not happen [authors' translation]." These responses demonstrate a lack of knowledge and understanding of what IICs are for both professors and students.

\section{DISCUSSION}

This study has shown that both teachers and students participating in an EMI experience have positive perceptions, but also acknowledge 
that it has challenges. On the one hand, students and teachers have the opportunity to use language in authentic communicative situations and can enhance their technical vocabulary knowledge. Furthermore, as David Marsh (personal communication, September 8, 2016) argues, one of the main reasons why the CLIL and EMI approaches began was to foster confidence in the students to allow them to "join" the international conversation on their discipline in English. This is precisely what was found in this study. Students built confidence when using the language and became aware of their capacity to use English to learn content. They also were more willing to take communicative risks in English.

Taking EMI courses also fosters additional benefits that are directly related to internationalization initiatives. These include opportunities for students to interact with international students in their classes and participate in outbound mobility themselves. Further, as all participants noted, working in English in their academic courses potentially prepares them for their future professional needs.

Conversely, EMI courses may pose some challenges for students and professors. First, the success of the course hinges upon the language levels and attitudes of all participants. Thus, if the students do not have a competent language level and a positive outlook towards the course, the teaching and learning are affected and may impact the whole experience. Professors would most likely recur to the native language to reduce student anxiety and create a safe learning environment, and the students would, therefore, miss the opportunity to use English meaningfully. Therefore, institutions should make decisions about language level requirements needed to participate in EMI courses.

Also, professors' attitude and teaching style are essential for the success of the experience. In this particular study, the actions and discourse used by the professors set the tone of the classes. It was evident that one of them tried to create rapport, foster an interactive classroom, and show the benefits of using English in the course while there was an obvious difference in the attitude of the other professor. Thus, the selection of teachers for an EMI experience should be voluntary.

Finally, the development of IICs should be seen as one of the central outcomes of an EMI experience. However, the study revealed that there is 
no clear understanding of what IICs are, which are expected to developed in the courses, and how and whether this development is assessed. While one of the areas of IIC relates to foreign language competence, other essential skills that could result from the participation in EMI experiences are neglected.

\section{Recommendations}

These conclusions led us to propose several recommendations to take full advantage of EMI courses. We have classified them into three levels: institutional-, professor-, and student-oriented.

The most important recommendation we can give at the institutional level is defining overarching international and intercultural competences that create a clear foundation for the implementation of EMI courses. Having a clear purpose will allow all parts of the university community to not only understand the importance of this type of initiative but also to work strategically towards the established goals. Similar initiatives can be seen at HEIs around the world (see USF's Global Citizens Project and the University of Minnesota's ICC Program).

Related to this, EMI experiences should not be implemented in a vacuum. Each institution should devise clear guidelines for the use of EMI that include explaining the purpose of using English medium instruction; selecting subject-appropriate courses in which English could be meaningfully used; inviting professors to teach EMI courses, based on their interest and language level; and determining appropriate times to start EMI experiences (i.e., in what semester to offer courses in English) in order to assure that students have the necessary language level. All of these decisions should be effectively communicated to the entire university community to avoid misconceptions and allow for proper allocation of resources.

Another essential institutional-level action is related to providing support to professors involved in EMI delivery. This support would allow for opportunities to share, discuss, and broaden their knowledge and methodological practice to cope with the challenges of teaching EMI. We suggest that these faculty learning opportunities be inter-disciplinary to have varied perspectives on the topic. The delivery of this faculty support 
could be formal, such as set courses and teacher development seminars, or informal such as faculty/professional learning communities; likewise, they could be offered online or face-to-face.

Universities implementing this type of course also must pay close attention to the language education of their students. English language programs should aim to develop academic and communicative competences to the level that students can actively participate in field-related discussions. As stated by the participants in this study, the students' language level is key to the success of the course. Therefore, special attention should be given with regards to when students can enroll in EMI courses.

At the professor level, the main recommendation that we offer is related to a systematic approach to the use of English. In order to reap the most benefit from the EMI experience, we suggest that the great majority of the class time should be in English, including lectures, question and answer sessions, materials, and assessments. Therefore, professors should employ a wide range of strategies to facilitate learning. Among these strategies we recommend using communication techniques such as paraphrasing, repetition, circumlocution, among others; recurring to the native language only in strategic moments; creating safe learning environments where students can take risks to use the language; and promoting effective learning strategies.

Another essential recommendation relates to raising professors' awareness about the fact that students are continuing to develop language. Thus, because English is the vehicle for learning the content, it could impact students' understanding of the subject. This means that professors should try to adjust their course activities, lecturing modes, materials, and assessments, not to "water down" the content, but rather to accommodate for learning in a foreign language. As Ball and Lindsay (2013) contend, "in very simple terms, you cannot teach the same conceptual material to a native speaker in the same way as you can to a non-native speaker" (p. 46). In addition to the other changes mentioned above, professors should be aware that students may need more time to formulate questions and give answers. Therefore, this extra time should be provided since it does not mean that students do not know the content but rather that they are processing the information and expressing it in a language that is not their native. 
Studies have demonstrated that when language support is integrated with content, as occurs in CLIL classrooms, students benefit by learning content effectively (Pérez-Cañado, 2012). Therefore, we suggest that EMI professors should assess the benefits of implementing some CLIL features into their practice. Because they are experts in their content, collaborating with language specialists could allow them to identify the language aspects that can affect content comprehension and possibly implement strategies to overcome them.

One strategy that is essential in CLIL is scaffolding both language and content. Scaffolding in education refers to providing students with assistance that is slowly removed in order to help students advance from their existing to a higher level of understanding (Dafouz, Llinares, \& Morton, 2010). Using a type of scaffolding such as designing a series of activities that take students progressively from previously studied information to the understanding of new concepts could be a way to support student learning in the EMI class. Another way to scaffold is to provide reading guides, create vocabulary glossaries, and divide tasks into stages.

While most EMI teachers refuse to provide language feedback, we feel that if they do not, they miss valuable opportunities to help students develop more effective communication in their field. This does not imply devoting specific class time to correcting students' errors, but rather as an integral part of the class, professors could address some language issues through recasting, reformulation, echoing, and using body language.

All of the previous recommendations are closely related to an essential aspect when designing a CLIL course: identifying the language features necessary to cope with an EMI class. This identification refers not only to specific vocabulary and content-related language but also to discourse likely to be used in classroom interaction (known as the language for learning, of learning, and through learning by Coyle et al., 2010). Therefore, having this awareness could enable EMI teachers to identify the most common language features they use and adapt them for the class without diluting the content (Teemant, Bernhardt, \& Rodríguez-Muñoz, 1997).

The last level of recommendations relates to students. As professors need to exert themselves to deliver effective EMI, students must also put forth extra effort both before and during the class. Before the class session, 
students should read the materials and review the notes taken in the previous class. This could be done jointly with their peers by checking for understanding of the concepts and, if possible, reviewing language likely to occur in the class. During the class, students should be active learners and find strategies that suit their personal learning styles such as taking notes in both English and Spanish, using visual representations of concepts, creating technical glossaries, and most importantly, taking risks with the language in class.

As EMI implementation is new to the Latin American university context, further research is needed to document its real use, its effectiveness, and the role it has on the internationalization processes in higher education institutions. Furthermore, it is clear that much research needs to be done as to the effect of EMI on the development of international and intercultural competences at the university level.

\section{REFERENCES}

Aguilar, M. (2015). Engineering lecturers' views on CLIL and EMI. International Journal of Education and Bilingualism, 1-14. http:// dx.doi.org/10.1080/13670050.2015.1073664

Aguilar, M., \& Rodríguez, R. (2012). Implementing CLIL at a Spanish university: Lecturer and student perceptions. The International Journal of Bilingual Education and Bilingualism, 15, 183-197.

Airey, J. (2011). Talking about teaching in English: Swedish university lecturers' experiences of changing teaching language. Ibérica, 22, 35-54.

Airey, J. \& Linder, C. (2006). Language and the experience of learning university physics in Sweden. Institute of Physics Publishing, 27, 553-560.

Ali, N. L. (2013). A changing paradigm in language planning: Englishmedium instruction policy at the tertiary level in Malaysia. Language Awareness, 14(1), 73-92.

Altbach, P. G. (2004). Globalisation and the university: Myths and realities in an unequal world. Tertiary Education and Management, 10(1), 3-25. 
Ball, P. \& Lindsay, D. (2013). Language demands and support for Englishmedium instruction in tertiary education. Learning from a specific context. In A. Doiz, D. Lasagabaster, \& J. Sierra, English-medium instruction at universities world-wide: Global challenges (pp. 4161). Bristol, UK: Multilingual Matters.

Beelen, J. \& Jones, E. (2015, Winter). Looking back at the 15 years of internationalization at home. EAIE Forum, 6-8.

Bennett, J. M. \& Bennett, M. J. (2004). Developing intercultural sensitivity: An integrative approach to global and domestic diversity. In D. Landis, J. Bennett, \& M. Bennett (Eds.), Handbook of intercultural training (pp. 147-165). Thousand Oaks, CA: Sage.

Bogdan, R. C. \& Biklen, S. R. (1992). Qualitative research for education: An introduction to theory and methods (2nd ed). Boston, MA: Allyn and Bacon.

Byram, M. (1997). Teaching and assessing intercultural communicative competence. Clevedon, UK: Multilingual Matters.

Byun, K., Chu, H., Kim, M., Park, I., Kim, S., \& Jung, J. (2011). English-medium teaching in Korean higher education: Policy debates and reality. Higher Education, 62, 431-449. http://dx.doi.org/10.1007/s10734010-9397-4

Coleman, J. A. (2006). English-medium teaching in European higher education. Language Teaching, 39, 1-14.

Corrales, K., Ferrer, E. \& Rey, L. (2015). Perspectives on teaching universitylevel English in Colombia. Alexandria, VA: TESOL Press.

Costa, F. (2012). Focus on form in ICLHE lectures in Italy: Evidence from English-medium science lectures by native speakers of Italian. AILA Review, 25, 30-47. http://dx.doi.org/10.1075/aila.25.03cos

Costa, F. \& Coleman, J. A. (2013). A survey of English-medium instruction in Italian higher education. International Journal of Bilingual Education and Bilingualism, 16(1), 3-19. http://dx.doi.org/10.108o/ 13670050.2012 .676621

Cots, J. M., Lasagabaster, D. \& Garrett, P. (2012). Multilingual policies and practices of universities in three bilingual regions of Europe. International Journal of the Sociology of Language, 216, 7-32. 
Coyle, D., Hood, P. \& Marsh, D. (2010). CLIL: Content and language integrated learning. Cambridge, UK: Cambridge University Press.

Dafouz Milne, E., Llinares, A. \& Morton, T. (2010). CLIL across contexts: A scaffolding framework for CLIL teacher education. View[z] Vienna English Working Papers, 19(3), 12-20. Retrieved from http://www. unifg.it/sites/default/files/allegatiparagrafo/21-01-2014/views_ current_research_on_clil_3.pdf

deWit,H.[Cedu Uninorte].(2016, April 7).Modelos para la internacionalización en América Latina [Video file]. Retrieved from https://youtu.be/ UVt4LR6kUoM

Deardorff, D. K. (2004). The identification and assessment of intercultural competence as a student outcome of international education at institutions of higher education in the United States. Unpublished doctoral dissertation, North Carolina State University, Raleigh, NC. Retrived from http://www.lib.ncsu.edu/resolver/1840.16/5733

Deardorff, D. K. (2006). The identification and assessment of intercultural competence as a student outcome of internationalization at institutions of higher education in the United States. Journal of Studies in International Education, 10, 241-266.

Dervin, F. \& Hahl, K. (2015). Developing a portfolio of intercultural competences in teacher education: The case of a Finnish international program. Scandinavian Journal of Educational Research, 59(1), 95-109. http://dx.doi.org/10.1080/00313831.201. 904413

Doiz, A., Lasagabaster, D. \& Sierra, J. M. (2011). Internationalisation, multilingualism and English-medium instruction. World Englishes, 30(3), 345-359.

Doiz, A., Lasagabaster, D. \& Sierra, J. M. (2013). What does 'international university? Mean at a European bilingual university? The role of languages and culture. Language Awareness, 23(1-2), 1-15. http:// dx.doi.org/10.1080/09658416.2013.863895

Gazzola, M. (2012). The linguistic implications of academic performance indicators: General trends and case study. International Journal of the Sociology of Language, 216, 131-156. 
Greere, A., \& Räsänen, A. (2008). Year one report. LANQUA subproject on content and language integrated learning: Redefining 'CLIL'Towards multilingual competence. Retrieved from: http:// www.lanqua.eu/files/YearıReport_CLIL_ForUpload_Without Appendices_o.pdf

Haigh, M. (2014). From internationalisation to education for global citizenship: A multi-layered history. Higher Education Quarterly, 68(1), 6-27.

Hu, G., Li, L., \& Lei, J. (2014). English-medium instruction at a Chinese university: Rhetoric and reality. Language Policy, 13, 21-40. http:// dx.doi.org/10.1007/s10993-013-9298-3

Jensen, C., \& Thøgersen, J. (2011). Lecturing undergraduate science in Danish and in English: A comparison of speaking rate and rhetorical style. Journal of English for Specific Purposes, 30, 209-221.

Kırkgöz, Y. (2009). Students' and lecturers' perceptions of the effectiveness of foreign language instruction in an English-medium university in Turkey. Teaching in Higher Education, 14(1), 81-93.

Knight, J. (2003). Updated internationalization definition. International Higher Education, 33, 2-3.

Kubota, R. (2009). Internationalization of universities: Paradoxes and responsibilities. The Modern Language Journal, 93(4), 612-616.

Ljosland, R. (2011). English as an academic lingua franca: Language policies and multilingual practices in a Norwegian university. Journal of Pragmatics, 43, 991-1004.

Maiworm, F., \& Wätcher, B. (Eds.). (2002). English-language-taught degree programmes in European higher education: Trends and success factors. Bonn:Lemmens. Retrieved from http://www.lemmens.de/ dateien/medien/buecher-ebooks/aca/2002_english-languagetaught_degree_programmes_in_european_higher_education.pdf Montgomery, M. (2008). Global futures, global communities? The role of culture, language and communications in an internationalised university. In H. Haberland, J. Mortensen, A. Frabicius, B. Preisler, K. Risager, \& S. Kjaerbeck (Eds.), Higher education in the global village: Cultural and linguistic practices in the international 
university (pp.17-34). Roskilde, Denmark: Department of Culture and Identity, Roskilde University.

Mortensen, J. \& Haberland, H. (2012). English — the new Latin of academia? Danish universities as a case. International Journal of the Sociology of Language, 216, 175-197.

Olsen, L. A., \& Huckin, T.H.(1990). Point-driven understanding in engineering lecture comprehension. English for Specific Purposes, 9, 33-47.

Paseka, A. (2000). Towards internationalisation in teacher education: An attempt to use English as the working language in a sociology course. Teaching in Higher Education, 5(3), 359-371.

Pérez-Cañado, M. L. (2012). CLIL research in Europe: Past, present, and future. International Journal of Bilingual Education and Bilingualism, 15(3), 315-341. http://dx.doi.org/10.1080/13670050.2011.630064

Ruiz-Garrido, M. F., \& Palmer-Silveira, J. C. (2008). Content learning in business communication: A teaching experience within new European framework. In I. Fortanet \& C. Räisänen (Eds.), ESP in European Higher Education (pp. 147-164). Amsterdam, the Netherlands: Benjamins.

Sercu, L. (2004). The introduction of English-medium instruction in university: A comparison of Flemish lecturers' and student' language skills, perceptions and attitudes. In R. Wilkinson and $\mathrm{V}$. Zegers (Eds.), Integrating content and language: Meeting the challenge of a multilingual higher education (pp. 547-555). Maastricht, the Netherlands: Maastricht University.

Sert, N. (2008). The language of instruction dilemma in the Turkish context. An International Journal of Educational Technology and Applied Linguistics, 36(2), 156-171.

Smit, U., \& Dafouz, E. (2012). Integrating content and language in higher education. An introduction to English-medium policies, conceptual issues and research practices across Europe. AILA Review, 25, 1-12.

Soria, K. M., \& Troisi, J. (2014). Internationalization at home alternatives to study abroad: Implications for students' development of global, international, and intercultural competencies. Journal of Studies in International Education, 18(3), 261-280. 
Söderlundh, H. (2013). Applying transnational strategies locally: English as a medium of instruction in Swedish higher education. Nordic Journal of English Studies, 13(1), 113-132.

Spiro, J. (2011). Guided interaction as intercultural learning: Designing internationalisation into a mixed delivery teacher education programme. Higher Education Research \& Development, 30(5), 635646. http://dx.doi.org/10.1080/07294360.2011.598453.

Teemant, A., Bernhardt, E. \& Rodriguez-Muñoz, M. (1997). Collaborating with content-area teachers: What we need to share. In M.A.Snow \& D. M. Brinton (Eds.), The content-based classroom: Perspectives on integrating language and content (pp. 311-318). White Plains, NY: Longman.

Unterberger, B. (2012). English-medium programmes at Austrian business faculties. In U. Smit \& E. Dafouz (Eds.), Integrating content and language in higher education (pp. 80-100). Amsterdam, the Netherlands: Benjamins.

Wächter, B. \& Maiworm, F. (Eds.). (2014). English-taught programmes in European higher education: The state of play in 2014. Bonn, Germany: Lemmens. Retrieved from: http://www.aca-secretariat. be/index.php?id=792

Wächter, B. \& Maiworm, F. (2008). English-taught programmes in European higher education: The picture in 2007. Bonn: Lemmens. Retrieved from http://www.lemmens.de/dateien/medien/buecher-ebooks/ aca/2008_english-taught_programmes_in_european_higher_ education_-_the_picture_in_2007.pdf

Yang, R. (2002). University internalization: Its meanings, rationales and implications. Intercultural Education, 13(1), 81-95. 